\title{
Estimation of Optimum Available Phosphorous Extraction Methods for Reddish Brown Earth Soil
}

\author{
S.N.B.G.L.D. Kumara, D.M.S. Duminda*, J.P.H.U. Jayaneththi \\ Department of Agricultural Engineering and Soil Science, Rajarata University, Sri Lanka \\ *dmsduminda@yahoo.com
}

\begin{abstract}
Several extraction methods are used to determine plant available Phosphorus $(\mathrm{P})$ that affect for growth and yield of plants. This study was conducted to evaluate the different available $\mathrm{P}$ extraction methods for reddish brown earth (RBE) soil in dry zone of Sri Lanka. The experiment was conducted as a randomised complete block design (RCBD) with four replicates at Kahatagasdigiliya in Anuradhapura district during Maha (2013/2014) season. Seven extraction methods, i.e., Olsen's, Bray 1, Borax, Mehlich III, Modified Kelowna, ammonium chloride and distilled water were tested. Soil samples were collected at the tasseling stage of maize plants (Zea mays L.) treated with four fertiliser rates: 0 (T1), 20 (T2), 30 (T3) and 40 (T4) $\mathrm{kg}$ of $\mathrm{P} \mathrm{ha}^{-1}$. Soil samples were analysed for $\mathrm{pH}$, available $\mathrm{P}$ and total $\mathrm{P}$ apart the initial chemical characterisation. The effect of extraction methods for soil available $\mathrm{P}$ and the $\mathrm{P}$ recovery, interactions among the $\mathrm{P}$ levels with different extraction methods were evaluated. Available $\mathrm{P}$ extraction and $\mathrm{P}$ recovery using Modified Kelowna method was significantly greater than other methods $(\mathrm{p}<0.05)$. Olsen's, Bray 1, Borax, Mehlich III, Ammonium Chloride extraction methods were not significantly different $(p>0.05)$ in available $\mathrm{P}$ determination. The extraction methods and fertiliser levels were significantly different $(\mathrm{p}<0.05)$ with soil available $\mathrm{P}$. The $\mathrm{P}$ extraction in T4 was comparatively higher than other methods except distilled water extraction. Modified Kelowna method was most appropriate in available $\mathrm{P}$ extraction under experimental conditions in RBE soil.
\end{abstract}

Keywords: Phosphorus, $\mathrm{P}$ extraction methods, P recovery, RBE 